\title{
Teaching NeuroImages: Ohtahara Syndrome due to Unilateral Perisylvian Polymicrogyria
}

Sabarish Sekar, MD, DNB, Pavankumar Rudrabhatla, MD, Vinayagamani Selvadasan, MD, DNB, DM, Bejoy Thomas, MD, DNB, PDCC, and Chandrasekharan Kesavadas, MD

Neurolog ${ }^{\circledR}$ 2021;96:e2456-e2457. doi:10.1212/WNL.0000000000011497

Figure MRI and EEG
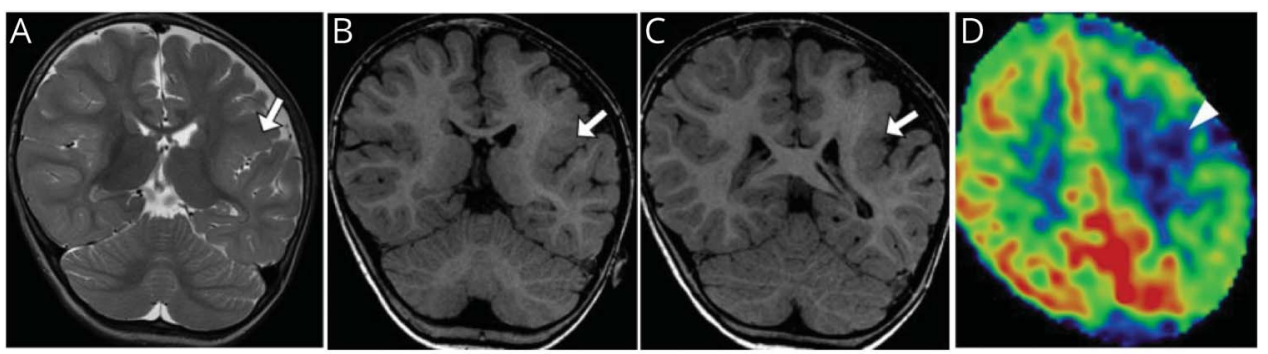

E

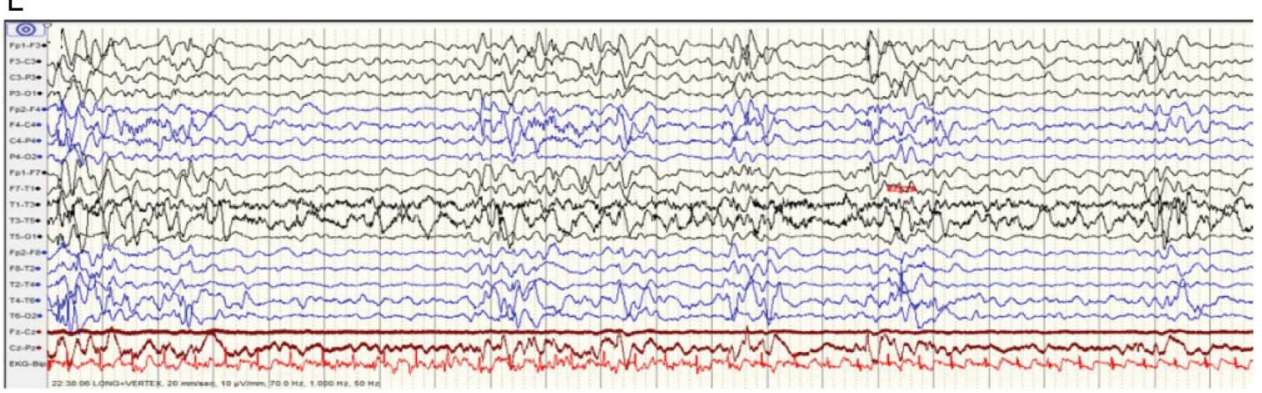

Coronal T2 (A) and coronal T1 (B, C) images show left perisylvian polymicrogyria (A), abnormally thick and bumpy coarse appearance of cortex (B), and widening of sylvian fissure (C). (D) Arterial spin labeling (postlabeling delay 2,500 ms) image shows left perisylvian hypoperfusion corresponding to polymicrogyria (arrowhead). (E) EEG shows typical burst-suppression pattern (time base: $20 \mathrm{~mm} / \mathrm{s}$, gain: $10 \mu \mathrm{V} / \mathrm{mm}$, high-frequency filter: $70 \mathrm{~Hz}$, low-frequency filter: $1 \mathrm{~Hz}$ ).

A 10-month-old boy, born of nonconsanguineous parents, without any perinatal insult, presented with tonic spasms from the 13th day of life. He started having tonic seizures from 4 months of age, with global developmental delay. On examination, there were no neurocutaneous markers, facial dysmorphism, or focal neurologic deficits. EEG (figure) showed generalized and multifocal epileptiform discharges along with burst-suppression pattern. MRI of brain revealed left perisylvian polymicrogyria (figure).

Ohtahara syndrome is an electroclinical syndrome, characterized by infantile-onset epileptic encephalopathy and typical burst-suppression pattern on EEG, which remains unchanged during sleep and wakefulness. ${ }^{1}$ It is most commonly associated with structural malformations including neuronal migration disorder or dysgenesis, mutations in genes including $A R X$, CDKL5, SLC25A22, STXBP1, and KCNQ2, and various metabolic disorders. ${ }^{1,2}$ Presence of structural malformations, like left-sided perisylvian polymicrogyria in our case, precludes

\section{Correspondence}

Dr. Sekar

sabarish.ss.dr@gmail.com

\section{MORE ONLINE}

$\rightarrow$ Teaching slides

http://links.lww.com/

$\mathrm{WNL} / \mathrm{B} 303$

From the Department of Imaging Sciences and Interventional Radiology (S.S., B.T., C.K.), Department of Neurology (P.R.), and Department of Imaging Sciences and Interventional Radiology (V.S.), Sree Chitra Tirunal Institute for Medical Sciences and Technology, Trivandrum, India. 
extensive genetic and metabolic analysis and differentiates it from early myoclonic encephalopathy.

\section{Study Funding}

No targeted funding reported.

\section{Disclosure}

The authors report no disclosures relevant to the manuscript. Go to Neurology.org/N for full disclosures.

Appendix Authors

\begin{tabular}{|c|c|c|}
\hline Name & Location & Contribution \\
\hline $\begin{array}{l}\text { Sabarish Sekar, } \\
\text { MD, DNB }\end{array}$ & $\begin{array}{l}\text { Department of Imaging } \\
\text { Sciences and } \\
\text { Intervention Radiology, } \\
\text { Sree Chitra Tirunal } \\
\text { Institute for Medical } \\
\text { Sciences and } \\
\text { Technology, } \\
\text { Thiruvananthapuram, } \\
\text { Kerala, India }\end{array}$ & $\begin{array}{l}\text { Major role in } \\
\text { acquisition of data, } \\
\text { study concept, design } \\
\text { and drafting of the } \\
\text { manuscript }\end{array}$ \\
\hline $\begin{array}{l}\text { Pavankumar } \\
\text { Rudrabhatla, MD }\end{array}$ & $\begin{array}{l}\text { Department of } \\
\text { Neurology, Sree Chitra } \\
\text { Tirunal Institute for } \\
\text { Medical Sciences and } \\
\text { Technology, } \\
\text { Thiruvananthapuram, } \\
\text { Kerala, India }\end{array}$ & $\begin{array}{l}\text { Major role in } \\
\text { acquisition of data and } \\
\text { EEG discussion }\end{array}$ \\
\hline
\end{tabular}

Appendix (continued)

\begin{tabular}{|c|c|c|}
\hline Name & Location & Contribution \\
\hline $\begin{array}{l}\text { Vinayagamani } \\
\text { Selvadasan, MD, } \\
\text { DNB, DM }\end{array}$ & $\begin{array}{l}\text { Department of Imaging } \\
\text { Sciences and Intervention } \\
\text { Radiology, Sree Chitra } \\
\text { Tirunal Institute for } \\
\text { Medical Sciences and } \\
\text { Technology, } \\
\text { Thiruvananthapuram, } \\
\text { Kerala, India }\end{array}$ & $\begin{array}{l}\text { Study concept and } \\
\text { design, revision of } \\
\text { manuscript }\end{array}$ \\
\hline $\begin{array}{l}\text { Bejoy Thomas, } \\
\text { MD, DNB, PDCC }\end{array}$ & $\begin{array}{l}\text { Department of Imaging } \\
\text { Sciences and Intervention } \\
\text { Radiology, Sree Chitra } \\
\text { Tirunal Institute for } \\
\text { Medical Sciences and } \\
\text { Technology, } \\
\text { Thiruvananthapuram, } \\
\text { Kerala, India }\end{array}$ & $\begin{array}{l}\text { Critical revision of } \\
\text { manuscript }\end{array}$ \\
\hline $\begin{array}{l}\text { Chandrasekharan } \\
\text { Kesavadas, MD }\end{array}$ & $\begin{array}{l}\text { Department of Imaging } \\
\text { Sciences and Intervention } \\
\text { Radiology, Sree Chitra } \\
\text { Tirunal Institute for } \\
\text { Medical Sciences and } \\
\text { Technology, } \\
\text { Thiruvananthapuram, } \\
\text { Kerala, India }\end{array}$ & $\begin{array}{l}\text { Critical revision of } \\
\text { manuscript }\end{array}$ \\
\hline
\end{tabular}

\section{References}

1. Beal JC, Cherian K, Moshe SL. Early-onset epileptic encephalopathies: Ohtahara syndrome and early myoclonic encephalopathy. Pediatr Neurol 2012;47:317-323.

2. Pavone P, Spalice A, Polizzi A, Parisi P, Ruggieri M. Ohtahara syndrome with emphasis on recent genetic discovery. Brain Dev 2012;34:459-468. 


\section{Neurology}

\section{Teaching NeuroImages: Ohtahara Syndrome due to Unilateral Perisylvian Polymicrogyria \\ Sabarish Sekar, Pavankumar Rudrabhatla, Vinayagamani Selvadasan, et al.}

Neurology 2021;96;e2456-e2457 Published Online before print January 5, 2021

DOI 10.1212/WNL.0000000000011497

\section{This information is current as of January 5, 2021}

\section{Updated Information \& Services}

References

Subspecialty Collections

Permissions \& Licensing

Reprints including high resolution figures, can be found at: http://n.neurology.org/content/96/19/e2456.full

This article cites 2 articles, 0 of which you can access for free at: http://n.neurology.org/content/96/19/e2456.full\#ref-list-1

This article, along with others on similar topics, appears in the following collection(s):

Cortical dysplasia

http://n.neurology.org/cgi/collection/cortical_dysplasia

EEG

http://n.neurology.org/cgi/collection/eeg_

Infantile spasms

http://n.neurology.org/cgi/collection/infantile_spasms

Information about reproducing this article in parts (figures,tables) or in its entirety can be found online at:

http://www.neurology.org/about/about_the_journal\#permissions

Information about ordering reprints can be found online:

http://n.neurology.org/subscribers/advertise

Neurology ${ }^{\circledR}$ is the official journal of the American Academy of Neurology. Published continuously since 1951, it is now a weekly with 48 issues per year. Copyright @ 2021 American Academy of Neurology. All rights reserved. Print ISSN: 0028-3878. Online ISSN: 1526-632X.

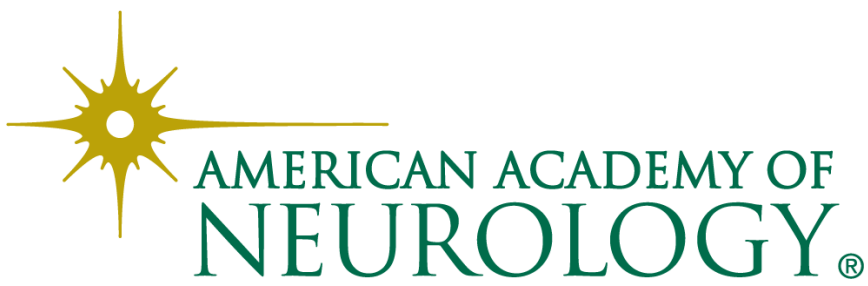

